\title{
Pedagogical Conditions of Students Independent Readiness Formation for Educational Cognitive Activity
}

\author{
Rais Semigullovich Safin ${ }^{1}$, Evgeny Alexandrovich Korchagin ${ }^{1}$, Viktoriya Arkadyevna Elizarova ${ }^{2}$, Ilfak \\ Elfikovich Vildanov ${ }^{1}$, Runar Nazilovich Abitov ${ }^{1}$, Nataliya Alekseyevna Kora ${ }^{3}$ \& Venera Marsovna \\ Nigmetzyanova ${ }^{4}$ \\ ${ }^{1}$ Kazan State University of Architecture and Engineering, Tatarstan, Kazan, Russian Federation \\ ${ }^{2}$ Shakhty Design and Service College "Don-Tex", Rostov region, Russian Federation \\ ${ }^{3}$ Amur State University, Amur Region, Russian Federation \\ ${ }^{4}$ Naberezhnye Chelny Institute of Kazan Federal University, Tatarstan, Russian Federation \\ Correspondence: Rais Semigullovich Safin, Kazan State University of Architecture and Engineering, Tatarstan, \\ Kazan, 420043, Zelenaya Street, 1, Russian Federation. E-mail: safin@kgasu.ru
}

Received: October 3, 2014 Accepted: December 27, 2014 Online Published: January 14, 2015

doi:10.5539/ass.v11n4p269

URL: http://dx.doi.org/10.5539/ass.v11n4p269

\begin{abstract}
The purpose of the article consists in development and experimental check of pedagogical conditions efficiency of students' readiness formation for their own educational cognitive activity in the course of vocational training. The basis of this research forms axiological and competence-based approaches to a problem of students' readiness for their own educational cognitive activity in the course of vocational training in a higher education institution. The following conditions of the process efficiency as pedagogical ones are offered in this article. They are: complex scientific and methodical, educational and syllabus, information and technical providing of students readiness for independent educational cognitive activity in the course of vocational training; the motivational and appreciative attitude of students to independent educational cognitive activity in the course of vocational training; mark and rating monitoring of students readiness formation for independent educational cognitive activity in the course of vocational training. The results of this research are of value at creation and approbation of innovative methods of students' readiness formation for their independent educational cognitive activity, at creation of models of psychological and pedagogical maintenance of this process at the vocational educational institutions.
\end{abstract}

Keywords: independent educational cognitive activity, students, readiness formation, pedagogical conditions

\section{Introduction}

Development of economy of Russia changes requirements to professional staff cardinally. It is noted that the level of competitiveness of modern innovative economy is defined substantially by the quality of professional staff and by extent of their socialization and being cooperative in the Concept of long-term social and economic development of the Russian Federation for the period till 2020 (Concepts of long-term economic development of the Russian Federation for the period till 2020, 2009). Such experts who not only master perfectly their own profession are necessary to the country, those who participate in production improvement actively, but also those who seek for professional development, mastering adjacent professions. It causes new goal- oriented points of vocational training of future experts, among which is the formation of readiness for independent educational cognitive activity (Korchagin \& Safin, 2012; Shaidullina, 2012). Readiness of future experts for independent educational cognitive activity is a component of their creative potential, possibility to increase their competitiveness at the labor market, a factor of professional and career growth, self-realization during their whole life (Elizarova, 2013).

The peculiarities of students readiness formation for independent educational cognitive activity in the course of vocational training are caused by the following tendencies: 1) providing effectiveness of the knowledge, stipulating ability formation to realize the acquired knowledge in practice according to constantly changing requirements of production; 2) formation of steady interest to future profession, causing gradual development of complete system of professional and group, and individual and personal values (Masalimova, 2012; Safin et al., 
2013).

Independent educational cognitive activity of students carries out the following functions in the course of vocational training: 1) cognitive, focused on deepening general education and all-professional knowledge and expansion of vocational training type; 2) axiological, providing students formation of the steady motivational and valuable attitude to educational cognitive activity according to the chosen specialty; 3) conative, including the development of the general and professional competences which take into account individual and age peculiarities of students and level of their readiness; 4) integrative, directed on reflection of substantial and logical communications of the main educational syllabuses which pay attention to informative opportunities and previous preparation of the students (Elizarova, 2010).

\section{Materials and Methods}

In the early stages of experimental work, we have formulated the hypothesis that the process of formation of students' readiness to the self-educational-cognitive activity in the process of professional training will be effective if the following pedagogical conditions are identified: complex scientific and methodical, educational and syllabus, information and technical providing the students' readiness for independent educational cognitive activity in the course of vocational training; steady orientation of teachers towards the inclusion of individual and group forms of independent educational cognitive activity of future experts in the process of vocational training; the motivational and valuable attitude of students to independent educational cognitive activity in the course of vocational training; mark and rating monitoring of students' readiness formation for independent educational cognitive activity in the course of vocational training.

Skilled and experimental check work of pedagogical conditions of students readiness formation for independent educational cognitive activity in the course of vocational training was carried out on the basis of the public budgetary educational institution of secondary professional education of the Rostov region "The Shakhty technical college of design and the "Don-Teks" service, the public budgetary educational institution of primary professional education of the Rostov region "Professional lyceum No. 59" Novoshakhtinsk town.

512 students of Shakhty technical school of design and the "Don-Teks" service took part in the experiment. They are majoring for "A crafts-master of finishing and decorating construction works" at the public budgetary institution of secondary vocational education of the Rostov region. They were included in the experimental group, in which we have introduced the proposed pedagogical conditions of students' readiness forming to the self-educational-cognitive activity in the process of their professional training.

228 students majoring for "A crafts-master of finishing and decorating construction works" at the public budgetary educational institution of primary vocational education of the Rostov region "Professional lyceum No. 59 " were included in control group, which was followed only by ascertaining experiment.

The following methods of students' independent educational cognitive activity were applied in the course of the experiment. They can be divided into the following groups: methods of the organization of independent educational cognitive activity (gnostic, interactive methods, methods of common cultural and professional competences formation); stimulation and motivation methods; control and self-control methods.

The structure-forming components of future experts readiness for independent educational cognitive activity were the following: 1) the motivational: interest to educational and informative and future professional activity; perception of independent educational cognitive activity as purposeful process of self-improvement and development of common cultural and professional competences; 2) the intellectual: understanding of essence and knowing methods of independent educational cognitive activity; ability to plan and organize their own educational cognitive activity; 3 ) the determined: steady necessity for continuous self-development; ability to self-organization throughout the whole life in the course of realization of the right for education according to educational and professional requirements.

\section{Results}

There were three stages of skilled and experimental work: stating, forming and control.

The valuable orientations of students showed that the received results in experimental and control groups have insignificant divergences within a stating stage diagnosing. The most significant among terminal values were: in experimental group: health- $63 \%$, interesting work-56\%, a family-51\%. In control group: health-57\%, interesting work- $54 \%$, financially secure life- $48 \%$. The most significant values, while ranging them, became: in experimental group: education- $61 \%$, responsibility- $52 \%$, efficiency in affairs- $48 \%$; in control group: accuracy-59\%, responsibility- $50 \%$, diligence- $43 \%$. 
The program of an elective course "Organization of Independent Educational Cognitive Activity" was developed according to the results of a stating stage. Features of this program are in the formation of knowledge needs and abilities to implement the acquired knowledge in practice, taking into account the manufacture constant changing requirements, and also in the gradual development of an integral system of professional-group and personal values of student personality.

Complex (scientific and methodical, educational and syllabus information and technical) providing of future builders readiness formation for independent educational cognitive activity was approved in the course of the vocational training at the stating stage. It included:

- the textbook "Materials science" (dry construction), the manual "Technology of Frame Installation and Sheeting Constructions". It included variable tasks for independent educational cognitive activity, and also the electronic manual "Installation of Frame and Sheeting Constructions" which allowed studying an educational and syllabus material for students who missed the classes by themselves.

- scientific and methodical recommendations for teachers for students readiness formation to the independent educational cognitive activity, including instructive and technological cards, stands, "cases" of the competence-oriented tasks and so forth;

- educational and methodical recommendations for students for the organization of independent educational cognitive activity, for independent profound studying of syllabus subjects, and also for work with educational literature and internet resources according to subjects and professional modules of a syllabus;

- lists of obligatory and additional educational literature, internet resources according to subjects and professional modules of a professional syllabus number270802.10, that means" A crafts-master of finishing and decorating construction works.

The textbook for primary professional education students "Materials science (dry construction)" (M.: Publishing center "Akademiya", 2010, p. 304) and manual "Technology of Frame Installation and Sheeting Constructions" (M.: Publishing center "Akademiya", 2012, p. 192) received "FIRO" Federal State Institution recommendations for use in educational process of the educational institutions realizing programs of primary professional education by professions number 270802.08 "Drywall construction specialist" and number 270802.10 "A crafts-master of finishing and decorating construction works".

Developed and approved complex (scientific and methodical, educational and syllabus, information and technical) provision promoted not only the readiness of future builders formation for independent educational cognitive activity (preparation of cases, development of projects, etc.), but also the development of social and professional qualities of students (commitment, initiative, determination, persistence, endurance, discipline). It also promoted professional concepts assimilation and terms (the mechanized tool, frame and sheeting constructions, construction materials, etc.).

It is established that the steady motivational and valuable attitude of students for independent educational cognitive activity in the course of vocational training is characterized by aspiration to get knowledge and to be engaged in accumulation of professional experience in the future. It is also characterized by inquisitiveness, desire to be professionally active, ability to cooperation, and also such motives as "to become the qualified and competitive expert", "to continue a vocational education at higher educational institution successfully", "to provide success of future professional activity".

Experiment showed that rating monitoring of the process of the future builder readiness formation for independent educational cognitive activity stimulates their independent educational cognitive activity; increases competitiveness in the course of vocational training; reflects the level of their readiness for independent educational cognitive activity and promotes its timely correction.

The levels (reproductive, productive, creative) of future builders' readiness for independent educational cognitive activity in the course of vocational training on the basis of knowledge, motivational and determined criteria are revealed.

The criterion changes in readiness of future builders for independent educational cognitive activity in the course of vocational training (see table 1) were revealed on the basis of knowledge at a control stage of the experiment.

It is visible from table 1 that there were positive changes in readiness for independent educational cognitive activity in the course of vocational training among students of experimental group. 
Table 1. Dynamics of students' readiness for independent educational cognitive activity in the course of vocational training on the basis of knowledge criterion (as a percentage) in experimental (EG) and the control groups $(\mathrm{CG})$

\begin{tabular}{|c|c|c|c|c|c|}
\hline \multirow[t]{2}{*}{ № } & \multirow[t]{2}{*}{ Indices } & \multicolumn{2}{|c|}{$\begin{array}{l}\text { Stating } \\
\text { stage }\end{array}$} & \multicolumn{2}{|c|}{$\begin{array}{l}\text { Control } \\
\text { stage }\end{array}$} \\
\hline & & EG & $\mathrm{CG}$ & $\mathrm{EG}$ & $\mathrm{CG}$ \\
\hline 1 & $\begin{array}{l}\text { Ability to think independently (to define peculiarities of technology of sheet } \\
\text { materials installation, to find features of sheets joining, the design of internal and } \\
\text { external angles and points of conjugated with door-frames, etc.) }\end{array}$ & 27 & 24 & 51 & 30 \\
\hline 2 & $\begin{array}{l}\text { Ability to find the approach to the solution of a task (to accomplish the collection } \\
\text { of information and making up a "case", to develop projects on technology of } \\
\text { installation) }\end{array}$ & 38 & 27 & 64 & 29 \\
\hline 3 & $\begin{array}{l}\text { Educational cognitive activity self-goal-setting (to formulate the purpose of an } \\
\text { industrial practice task for independent educational cognitive activity) }\end{array}$ & 43 & 42 & 61 & 46 \\
\hline 4 & $\begin{array}{l}\text { Educational cognitive activity self-planning (to make the plan of performance of } \\
\text { an educational and informative task or a "case") }\end{array}$ & 38 & 37 & 63 & 40 \\
\hline 5 & $\begin{array}{l}\text { Educational cognitive activity self-organization (to plan time on collecting } \\
\text { materials for a "case" rationally, implementation of the project, the solution of } \\
\text { production target, etc.) }\end{array}$ & 37 & 33 & 68 & 30 \\
\hline
\end{tabular}

It is obvious from table 1 that students of experimental group have positive changes in readiness for independent educational cognitive activity in the course of vocational training.

The control stage of experiment showed that on the basis of motivational criterion positive dynamics in readiness of future builders for independent educational cognitive activity in the course of vocational training (see table 2) took place.

Table 2. Dynamics of terminal values of students in experimental and control groups (ranging)

\begin{tabular}{|c|c|c|c|c|c|}
\hline \multirow{2}{*}{ № } & \multirow{2}{*}{ Terminal values } & \multicolumn{2}{|c|}{ Stating stage } & \multicolumn{2}{|c|}{ Control stage } \\
\hline & & EG & $\mathrm{CG}$ & EG & $\mathrm{CG}$ \\
\hline 1 & Professional skill & 7 & 6 & 3 & 7 \\
\hline 2 & Health & 1 & 1 & 10 & 1 \\
\hline 3 & Career growth & 6 & 7 & 4 & 6 \\
\hline 4 & Interesting job & 4 & 2 & 6 & 2 \\
\hline 5 & Financially secure life & 2 & 3 & 7 & 3 \\
\hline 6 & Continuation of studying at the higher educational institution & 8 & 8 & 2 & 8 \\
\hline 7 & Knowledge providing the future professional activity success & 10 & 9 & 1 & 9 \\
\hline 8 & Family & 3 & 4 & 8 & 5 \\
\hline 9 & Public recognition & 5 & 5 & 9 & 4 \\
\hline 10 & Creativity & 9 & 10 & 5 & 10 \\
\hline
\end{tabular}

There were changes in an appreciation of instrumental values in experimental group. It is obvious from table 3 that students of experimental group have the three of the main instrumental values: professional competences; general competences; self-control.

There was positive dynamics at levels of readiness for independent educational cognitive activity of experimental group students.

The offered set of pedagogical conditions causes efficiency of students-future-builders readiness formation for independent educational cognitive activity in the course of vocational training.

\section{Discussions}

The analysis of literature showed that a number of researches is devoted to problems of students' readiness formation for independent educational cognitive activity. 
Table 3. Dynamics of instrumental values of students in experimental and control groups (ranging)

\begin{tabular}{llllll}
\hline № & Instrumental values & \multicolumn{2}{c}{ Stating stage } & \multicolumn{2}{c}{ Control stage } \\
\hline & & EG & CG & EG & CG \\
1 & Efficiency in business & 3 & 7 & 5 & 8 \\
2 & Professional competences & 8 & 8 & 1 & 7 \\
3 & Mutual respect & 6 & 6 & 9 & 6 \\
4 & Respect for labor & 7 & 5 & 8 & 5 \\
5 & Responsibility & 2 & 2 & 6 & 2 \\
6 & Self-control & 10 & 10 & 3 & 9 \\
7 & Education & 1 & 4 & 4 & 4 \\
8 & Diligence & 4 & 3 & 7 & 3 \\
9 & General competences & 9 & 9 & 2 & 10 \\
10 & Punctuality & 5 & 1 & 10 & 1 \\
\hline
\end{tabular}

Theoretical basics of independent educational cognitive activity of the students are covered by L. P. Aristova (1963), B. P. Yesipov (1961), A. A. Kirsanov (1982), D. V. Vilkeev (1961), N. G. Dayri (1966), N. A. Polovnikova (1975), etc.

The pecularities of independent educational cognitive activity in system of professional education are reflected in the researches of Y. I. Shamova (1982), A. M. Novikov (2001), E. F. Zeer (2009), V. S. Ledneva (1989), P. F. Kubrushko (2006), etc.

The questions of motivation of educational cognitive activity in the course of vocational training are investigated in the works of A. A. Verbitsky (1991), A. K. Markova (1996), N. F. Talyzina and others.

At the same time, the results of our research testify that, theoretical bases of students' readiness formation for independent educational cognitive activity in the course of vocational training are revealed insufficiently.

\section{Conclusion}

Thus, the set of pedagogical conditions of students readiness formation for independent educational cognitive activity (complex scientific and methodical, educational and syllabus, information and technical providing the students' readiness for independent educational cognitive activity in the course of vocational training; steady orientation of teachers towards the inclusion of individual and group forms of independent educational cognitive activity of future experts in the process of vocational training; the motivational and valuable attitude of students to independent educational cognitive activity in the course of vocational training; mark and rating monitoring of students' readiness formation for independent educational cognitive activity in the course of vocational training) is caused by the content of professional education, by the pedagogical relationship arising between a teacher and a student, by the motivational and valuable attitude of a student to vocational training, and also by using of pedagogical diagnostics and an assessment of independent educational and cognitive activity skills.

\section{References}

Aristova, L. P. (1963). Education students' cognitive independence in learning the basics of science: From the experience of Tatarstan school teachers (p. 54). Tashknigoizdat, Kazan.

Concepts of long-term economic development of the Russian Federation for the period till 2020. (2009). Approved by the order of the Government of the Russian Federation of November 17, 2008 of N 1662-p. Retrieved August 8, 2009, from http://www.economy.gov.ru/minec/activity/sections/fcp/rasp_2008_ n1662_red_08.08.2009

Dairy, N. G. (1966). Education history in high school. Cognitive activity of students and the effectiveness of training (p. 438). Education, Moscow.

Elizarova, V. A. (2010). Model formation of cognitive independence of pupils of primary vocational education. News of Southern Federal University. Pedagogical Sciences, 7, 153-159.

Elizarova, V. A. (2013). Self-learning and cognitive activity of students as a socio-personal value. News of Southern Federal University. Pedagogical Science, 2, 107-113.

Esipov, B. P. (1961). Independent work of students in the classroom (p. 178). Education, Moscow.

Kirsanov, A. A. (1982). Customization training activities as a pedagogical problem (p. 226). KSU, Kazan. 
Korchagin, E. A., \& Safin, R. S. (2012). Educational Cluster: Interaction of high school and companies (p. 165).

Kubrushko, P. F. (2006). The content of professional pedagogical education (p. 207). Gardariki Press, Moscow.

Lednev, V. S. (1989). The content of education (p. 359). High school Press, Moscow.

Markova, A. K. (1996). Psychology of professionalism (p. 308). Knowledge Press, Moscow.

Masalimova, A. R. (2012). Development of research competence of technical specialists in the process of intra-training. Kazan Pedagogical magazine, 3(93), 127-132.

Novikov, A. M. (2001). Professional education-new way of self education. Specialist, 5, 6-10.

Polovnikova, N. A. (1975). The system of pupil's cognitive power education (p. 101). Kazan State Pedagogical Institute, Kazan.

Safin, R. S., Korchagin, E. A., Vildanov, I. E., Abitov, R. N., Sharafutdinov, D. K., Suchkova, T. V., ..., Shkindereva, I. N. (2013). Scientific and methodological support of institutional interaction (state) and corporate professional education (p. 136).

Shaidullina, A. R. (2012). Regional Experience of Integration in System Vocational School-High School-Manufacture. Memories of Almetyevsk State Oil Institute, 2, 306-312.

Shamova, Y. I. (1982). Activation of pupils'activation (p. 208). Pedagogic, Moscow.

Talyzina, N. F. (2006). Educational psychology (p. 288). Publishing Center "Academy", Moscow.

Verbitsky, A. A. (1991). Active education in high school: Contextual approach (p. 207). Moscow.

Vilkeev, B. (1961). Development of cognitive activity and independence in students of evening (shift) schools in learning text (p. 74). KSU, Kazan.

Zeer, E. F. (2009). Psychology of professional development (p. 240). Academy Press, Moscow.

\section{Copyrights}

Copyright for this article is retained by the author(s), with first publication rights granted to the journal.

This is an open-access article distributed under the terms and conditions of the Creative Commons Attribution license (http://creativecommons.org/licenses/by/3.0/). 